\title{
Performance and performativity at heritage sites
}

\author{
GaynorBagnall* \\ Liverpool John Moores University
}

\section{Introduction}

This article reports findings from empirical research carried out by the author at two heritage sites in the north west of England. The research was conducted at the Museum of Science and Industry in Manchester and at Wigan Pier in Wigan. These sites are heritage-based attractions and both are registered as museums with the Museums and Galleries Commission. ${ }^{1}$ The Museum of Science and Industry (hereafter the Museum) opened at Manchester's Castlefield site in 1983. Significantly, its city centre location, and its situation in Castlefield, the first English urban heritage park, suggested that the Museum offered potential for exploring the role of heritage in urban economic regeneration. Moreover, as the Museum also claimed to be a 'place of fun and fascination, with working exhibits bringing the past vividly to life' (Museum of Science and Industry in Manchester nd: 4), it appeared to be a site whose approach to visitors was characterized by a shift away from traditional museum practices and towards a more democratizing style. Wigan Pier (hereafter the Pier) was opened in 1985, and is an important example of attempts by local authorities to use tourism and tourist sites to transform an area's image. Furthermore, the Pier with its use of live performances, simulacra, and tangible reconstructions appeared to epitomize many of the recent developments in the heritage industry.

The research design was based on a comparative case-study method of inquiry. ${ }^{2}$ The data derived from this study have led me to challenge the view, frequently to be found in museum literature, that visitors to such sites are passive, uncritical consumers of 'heritage'. Rather, as I argue here, the heritage consumption process is characterized by complexity and diversity in respect of visitors' faculties. The findings reported in this article show how a form of reminiscence is practised at the sites, a reminiscence that is informed by performativity (Kershaw 1994). I argue that performance and performativity are key social practices at such sites, and that the relationship between visitors and the sites is based as much on emotion and imagination as it is on cognition. Moreover, this emotional and imaginary relationship is engendered by the physicality of the process of consumption. My findings also confirm recent developments in audience research and particularly those associated with the work of Nicholas Abercombie and Brian Longhurst who identify an emergent paradigm of spectacle and performance (Abercrombie and Longhurst 1998). These sociologists suggest that contemporary society is characteristically performative and that there has been a spectaclization of place and person, in the sense that people themselves become the spectacle. They argue that the distance between audiences and performers has diminished; people perform and they see others as performers, they perform for an audience yet they are also members of a range of audiences. ${ }^{3}$ Thus, the visitor research which is reported in this article is underpinned by two key arguments. First, visitor research needs to take account of new directions in the sociology of audiences which suggest that in contemporary western societies people are both cultural consumers and producers. Secondly, as a growing body of research (Campbell 1987, Bagnall 1996, Abercrombie and Longhurst 1998) suggests, the emotions and the imagination are key dimensions of this aspect of contemporary audience activity.

In this article I also suggest that this ability to perform is related to the cultural literacy and competency of the visitors; that omnivorousness with respect to cultural consumption provides visitors with a range of resources with which to perform. However, I highlight the key role of memory, life histories, and personal and family narratives in enabling visitors to relate the consumption experience to a range of experienced and imagined worlds. The experience 
of consumption at the sites can be seen as part of the reflexive project of individualization (Bauman 1996, Beck 2000) but it is also a process that is firmly embedded in social relations. The narratives of self which are utilized by the visitors are given substance and are made meaningful through their relations to personal and cultural biographies and life histories.

\section{The Consumption Process}

I have shown elsewhere how, in making sense of the past at the two sites, visitors physically, emotionally, and imaginatively map 4 their consumption (Bagnall 1996). These forms of interconnected embodied mapping enable and enhance the visitor experience. In particular, they allow visitors to connect to personal and cultural memories and biographies, and to practice and perform a form of reminiscence. The key to this visitor experience is an 'emotional realism' (Ang 1985). This refers to the way in which the sites may engage visitors on an emotional and imaginary level, and engender feelings that are meaningful and 'real'. It is vital to recognize the significance of authenticity to the consumption experience. Thus, it is argued that the interconnected mappings are underpinned and supported by a desire for authenticity. Indeed, visitors to the Museum and the Pier sites were concerned with the sites' 'distinction' in terms of the authenticity of these places. However, it is suggested that this notion of authenticity was related as much to the context of everyday life as it was to notions of high culture (Bagnall et al.1997). In particular, visitors required that the sites generate emotionally authentic responses. They required a factual certitude that could be employed as a resource, as a form of cultural capital. However, it was a cultural capital that was more fluid, and more related to the everyday lives and life histories of the visitors than Bourdieu (1984) would allow.

The visitors' navigation through and consumption of the two sites was achieved physically as well as cognitively, and frequently the physical aspect had primacy. The importance of the physicality of a museum visit has been highlighted by Museums and Galleries magazine. In an amusing and perceptive article which focused on the experience of visiting London museums, the museum visit was characterized as a 'gruelling physical test for anyone' (Batty 1996:18) that needed careful pacing. The magazine duly supplied a 'museum-goers warm-up' and warned of the potential physical dangers of museum visiting, including exhaustion, dehydration, blisters, aching muscles, back pain, eye strain, and cricked necks (Batty 1996:18). It was wryly suggested that visitors take precautions to assist with this physical test, such as eating high protein snacks, taking regular rests and drinks, and carrying a fold-up chair. This discussion has implications beyond its entertainment value for it highlights and reinforces the findings from my study of the Museum and the Pier; that visits to such sites are very much a diverse physical experience. Thus the consumption of the visitors I studied was characterized by physicality, from the satisfaction of bodily needs such as hunger and thirst, to the embodiment of the past that is achieved through engagement with a whole range of physical sensations.

Visitors mapped their visit in terms of physical experience. The significance of this physical mapping was that it enabled the visitor to map and to perform their consumption emotionally and imaginatively so that they could endow the versions of the past offered by the sites with meaning. The physical stimulation of emotions and imagination was particularly noticeable at the Pier where the use of actors certainly heightened these aspects of the encounter. However, it was also detected at the Museum. There was an interconnection between the physicality of the experience and the emotions and imagination engendered. It is this emotional mapping that is now explored.

The findings reported here may usefully be placed within the wider context of the sociology of the emotions and emotional regulation. Here there has been a growing sense of how people's emotions may be organized within social settings and that emotional expression is subject to historical processes of social change and modernization. Recent investigations have shown how capitalist development has been associated with the expansion of types of work, such as that of the airline steward, in which an emotional content forms part of product. Such work involves 'emotional labour'. Arlie Hochschild (1983) showed how individuals are able to act feeling, and to engage in different levels of acting effort, 
dependent upon the social or work situation (Duncombe and Marsden 1993). Hochschild showed how individuals are involved in, and aware of the benefits of emotion management, 'people are made increasingly aware of incentives to use feeling' (Hochschild 1983:198). The ability to act out emotions, to engage in emotional work, was also discernible in the consumption behaviour of the visitors to the Museum and the Pier. However, it is important to note, that the performance of emotion is a more flexible, fluid and historical social practice than it is sometimes assumed to be. As Cas Wouters (1989) has argued, drawing on the now classical argument of Norbert Elias, individuals' abilities to use emotions as a means of orienting and manifesting themselves have increased and are attuned to the social practices of their society (Wouters 1989).

Colin Campbell, in The Romantic Ethic and the Spirit of Modern Capitalism (1987), provides a useful way of understanding these processes. In distinguishing between traditional and modern hedonism Campbell argues that a key characteristic of modern consumption is the way in which emotion acts as the link between mental images and physical stimuli. In particular, he argues that for emotions to be enjoyed, they must also be controlled, and adjustable in intensity, a process that is learnt through socialization experiences (Campbell 1987). Moreover, Campbell suggests that it is the power of imagination that enables individuals to achieve this emotional engagement and control. This interconnection between emotion and imagination is certainly borne out by the findings at the Museum and the Pier. However, it is important to say that this is a connection that is mediated by personal and cultural biographies.

Visitors utilize a form of emotional mapping in their consumption of sites like the Museum and the Pier. It is important to examine how the interrelation between the physical and emotional maps is displayed. Moreover, it is significant that this interconnected mapping does not necessarily lead to an acceptance, or a confirmatory reading of what the site offers. It can promote a quite different response; a critical, even rejective reading of the information or message exhibited at the museum. These two forms of emotional mapping, the confirmatory and the rejective can be seen to represent either ends of a continuum. Following Morley (1980), it can be argued that the middle ground of this continuum constitutes a 'negotiated' reading. The visitor may broadly accept the message of the site but 'by relating the message to some concrete or situated context... may modify or partially inflect the given preferred reading' (Morley 1980:89).

I discovered that the most common way of emotionally experiencing visits at both of the sites was a form of confirmatory emotional mapping. Thus, at the Museum and at the Pier the emotional response stimulated by the physicality of the experience led visitors to feel that they really were consuming the past, or getting a good idea of what life was like in the past. The content and presentation styles of the sites allowed visitors to experience an emotional realism. As I have already indicated this notion of emotional realism is derived from the work of len Ang $(1985,1996)$ on the consumption of television soap operas. Ang highlights the construction of melodramatic meanings and feelings in texts like the American television show, Dallas. Ang suggests that such shows are characterized by melodramatic features such as excessive plot structure, and a tendency to exaggeration and cliché. However, within the genre of the melodrama it is important that these clichés are not considered and appraised for their literal value, or for their realism, but 'as meaningful in so far as they solicit a highly charged emotional impact' (Ang 1996:89). Thus, the appeal of shows like Dallas is to do with the emotional impact that they evoke. Within this television genre it is the feelings that are mobilized that matter. Furthermore, this mobilization of emotions can lead viewers to a sense of imaginary identification with specific characters within the show (Ang 1996).

The concept of emotional realism can also be used to describe the way in which visitors at the Museum and Pier emotionally map their consumption of the past at the sites. The visitors that I interviewed identified with the emotions generated by the exhibits at the Museum and the Pier in ways that gave an authenticity to the feelings activated by the two sites. My findings suggest that the use of actors to recreate the past at the Pier is very important in stimulating the emotions and imagination of the visitors. The promenade playlets that the visitor follows around the site, and the other performances in which the visitor participates, seem to enhance the visit, and allow the visitors to experience a feeling of re- 
living the past: 'I think it's quite good, we enjoyed the performances, we thought that was convincing, we liked that, and she (daughter) was petrified in the Schoolroom' (P4, Female 34, Housewife). ${ }^{5}$ And,

'I think it was quite realistic, it gave you an idea more than just looking at displays.... I think now there's a feeling that kids today are getting less and less of a feel of what the past was really like so I think that the smells and the sounds are very important in creating that feeling without which they would just sort of be images to them, it was like in the class wasn't it (to Partner) people, some kids didn't even know what a piece of coal was ....Yes, even when they were shown it, so it's that, the thing, the actual smells in the mines and the feel, very important' (P1, Male 33, Social Worker).

The displays at the Pier provoked an emotional response that enabled my visitors to feel as if they had experienced a realistic version of the past. Visitors may have encountered real coal in a plastic mine, but there was no doubting the emotional impact it could engender, or the feelings that it could mobilize. This process could also be detected at the Museum:

'I always like the reconstructions, like in the sewer, I think they're great... because it really brings it home what it was like then' (M19, Female 52, Midwifery Manager), and 'My favourite part is in there (Air and Space Gallery), I love the aircraft, but I love the steam engines as well' (M26, Male 51, Primary Head Teacher).

Thus, one of the primary ways in which these sites may be said to invoke the nostalgic impulse is through an invitation to 'feel' something. This suggests that meaning is achieved through constructing a plausible experience, rather than presenting a series of facts (Sande 1984). A way of securing this plausibility is to encourage an emotional engagement with the sites such that visitors feel that they have a sense of place that is, moreover, their own sense of place.

This process was observed at both the Museum and the Pier, where visitors' emotional engagement with the sites allowed them to connect to the past through the use of personal or family memories. Visitors were seen to employ their biographies as a key resource in engendering emotional engagement with the sites. Moreover, visitors were also able to identify with memories that were part of their cultural biographies and narratives:

'I mean it's like the underground bit is all about the start of Manchester you know, because I mean me coming from Hulme, I was watching a bit on one of the televisions [one of the TV screens at the museum], and he said something about Old Hulme, and I listened because me mam was from Old Hulme' (M24, Female 21, Retail Assistant).

And

'Well I'm an engineer so I liked the Power house, you know the noise and the steam....Mind you I was fascinated by the textiles how they designed these things it was unbelievable.... I think the textiles certainly have an interest to all, especially when they have these machines running and you think that people worked in that for nay on 12 hours a day' (M16, Male 58, Electrical Engineer, Power Station).

This process was also very apparent at the Pier's historic classroom installation:

'Now these children have got slates, and we were saying we remember them when we were in the infants, having them, now that's taken us back a bit' (P21, Female 80, Retired), and 'Oh yes, a reminder of my youth, of my grandma's day and the mills, clogs, and the mine, yes definite reminders of my early days, parents and grandparents' (P28, Female 61, Retired Civil Servant).

Thus, I want to suggest that emotions can play a key role in bringing the past to life at such 
sites. This form of emotional mapping enables visitors to explore the past for themselves, and make history more meaningful to their lives and personal experience.

There is, however, no single visitor experience for it is possible for this invocation of emotions to stimulate a rejection of what is presented to the visitor. Thus, just as personal and family memories are used to support and confirm identification with the version of the past that is offered, so these narratives may also be employed to reject the story that is presented. Hence, these narratives are used to challenge the constructed nature of sites like the Museum and the Pier. There is a space for personal memory, a 'place for retelling' (Game 1991:163) at such sites. Personal and family memories can be used to rewrite the texts and to disrupt the constructed order of heritage sites. The stimulation of the emotions of visitors can encourage an unconscious and imaginary mapping of the sites. This may be a mapping that facilitates a feeling of 'being there', not in the sense of a nostalgic desire for the imaginary, but by being in a place where you know what happened, know the ways, and know what cannot be seen (de Certeau 1984). The 'affectivity of involuntary memory, as opposed to the voluntary memory of nostalgic discourse' (Game 1991:167) can, as Walter Benjamin suggests, stimulate memories that envelop the individual and disrupt the boundary between past and present (Savage 1993). This process can disrupt the specular, and allow visitors to refuse and reject the constructed nature of heritage sites such as the Museum and Pier.

Thus, I found that there was 'a way of being' at the Pier that involved a rejection of the structured consumption that the site invited. The Pier seemed to stimulate personal memories that allowed some visitors to refuse the particular construction and interpretations offered by the site. For example, the ability of the site to bring history to life was questioned:

'I think it's tempered with what people like you know your grandparents and that tell you, little things that you might say ooh I remember them saying that, those things, so it depends really' (P4, Female 34, Housewife).

And:

'at the pithead, there was a coal reel and a lift for coal, well I did that. It was only for two years but I did that aye (this was the job of cleaning and sorting coal at the Pithead). Well you know it was a hard life and I was brought up among the miners, you know I had three brothers and a father and I remember the 1926 strike and it was something terrible, oh, and that's the true picture for me anyway, because I lived through it all' (P 7, Female 83, Retired).

The use of personal and family memories to provide a critical, perhaps rejective, emotional mapping was also found at the Museum:

'We were saying that the most interesting bit is the sewer bit that was extremely interesting because there was actually lots of things there that we can remember when we were children. We were coming out and saying 'My God' we must be museum exhibits already, laughter, it's frightening, and because a bit of that I can remember from when I was a child it's not as old as they're depicting, they're saying when it started but not when it finished' (M 29, Female 51, Cashier).

And:

'It tells part of the tale, I mean it's a very wide tale you could write a book on it perhaps if there was a bit more shown of the industrial conditions at the start of the century, that I know about the way the people lived and some of the people who pioneered the developments in the city'(M 8, Male 37, Company Director).

However, it is important to note another way in which an emotional engagement with the sites can lead to a rejection of the presented past: here the museum-as-education and the visitor's emotions are separated through their strong classification in the visitor's consciousness. Thus, Henrietta Riegel (1996) writing of a 1992 exhibition in Stuttgart about the immediate post-war period reported the desire of some visitors for a cognitive distance from museum 
exhibitions. The Stuttgart exhibition did not use text panels or labels; their absence was an attempt to immerse visitors in recreations of war and post-war scenarios, such as a bombed-out cellar and a room depicting the plight of the 'Displaced Persons' (Riegel 1996:87). Some visitors complained about these exhibits claiming to feel too 'close' to them, and that they stimulated and reawakened unpleasant memories. Visitors claimed that they did not want to feel this emotional proximity; instead they wanted to look and to read. They 'had not anticipated re-experiencing the emotions attendant to those events' (Riegel 1996:87). They were shocked to find themselves and their recent past on display, and this resulted in the stimulation of memories that they didn't want to recall. These visitors expected a museum to educate them, not to stimulate their emotions. Consequently, they were keen to separate, and to mark as distinct, museum education and personal emotion.

Significantly, at the Pier staff told stories of visitors who had echoed the sentiments expressed by the visitors in Riegel's work. Visitors had found the Pier to be too emotionally resonant and did not want this emotional closeness as part of their visit. For example, one worker talked about a female visitor who had not wanted to visit inside the Mill. Hence,

'older people tell you about their memories, sad memories in some cases, you know one woman said, well, we was on about the mill, going over and watching the cotton spin, and she goes, oh, I used to work in the mill and l've seen enough of that I don't want to go in' (Senior Attendant).

This feeling of not wanting to connect to an emotionally charged past can also be detected in the following comment from a visitor to the Pier, 'No, it's nice to see I suppose but l've seen it all before and personally I think we prefer going forward to going back' (P21, Female 80, Retired). In these instances visitors are aware of the emotional appeal made by the sites, but reject this emotional 'closeness' in a desire to avoid the memories such an emotional engagement might awaken.

This suggests that visitors employ a range of emotional mappings to make sense of their visits. At the extremities of the range are confirmatory and rejective maps. In the main, this emotional mapping evokes a sense of engagement with the sites, such that visitors 'feel' as if they have had a 'taste' of life in the past. However, this mapping leads some visitors to reject the version of the past presented by the sites. This is achieved by the utilization of personal memories, which are employed to tear open the constructed nature of the sites, or by a rejection of the emotional closeness that the sites attempt to engender. The discussion above has highlighted the importance of memory and imaginary identification in the consumption practices of the visitors. The ability of imagination to enhance visitors' consumption at heritage sites is now examined in more detail.

In an earlier section it was suggested that the emotional appeal of the sites can lead visitors to experience a heightened sense of place. Moreover, it was maintained that a key way that this is secured is by the stimulation of imagination. As Appadurai (1993) has suggested, imagination is a key social practice. In particular he argues that contemporary people are immersed in the media, and inhabit a 'mediascape' (Appadurai 1993:278), which provides a range of images and narratives that can be employed to fuel the imagination.

Examination of the cultural activities of the visitors to the Museum and Pier indicated that they had access to a wide range of cultural resources. These people assimilated cultural information across a wide range of cultural genres and media. Visitors were culturally literate across a varied array of cultural pursuits. This literacy was evident at the Pier and the Museum, although it was wider and deeper at the Museum. Visitors extended their cultural knowledge across the whole cultural terrain. Furthermore, at both sites many people were extremely articulate when discussing their cultural life. Visitors to both sites employed a variety of cultural materials and resources to plan their cultural activities. Resources included a range of cultural genres from broadsheet newspapers and national trust information to local newspapers, television and word of mouth. As Warde et al. (1999) have suggested this 'varieagation' in the circulation of cultural items does have an impact on consumption. These visitors were armed with a wide array of cultural resources to assist their imaginary identifications. 
Importantly, as Campbell (1987) suggests, it is easier to imagine events or situations that produce an emotion in the imaginer, such as nostalgia. Consequently, as the Pier and the Museum are saturated with opportunities for nostalgia, they are prime sites for a form of consumption structured by emotional and imaginary mappings. People can with the skilful use of imagination, and imaginary identifications adjust the level and nature of the emotional experience (Campbell 1987). However, whilst the visitors at the Pier and Museum were to a degree, 'artists of the imagination' (Campbell 1987:78), able to take and make use of images from the memory, they were less able to re-craft and re-work them into unique entities. Rather they engaged in forms of reminiscing. Consequently, I maintain that the use of imagination is not random; it is mediated by biography and by a sense of emotional engagement. Visitors construct, and use as a resource, imagined worlds based on past and existing experiences and relationships through work, family and other social relationships. Significantly, it is the emotional engagement of visitors with such worlds that plays a major role in their ability to 'imagine' at the sites.

\section{Performing Reminiscence}

A central feature of imaginary mapping is the performance and stimulation of memories, a form of reminiscence that is informed by performativity, and emotional realism. Reminiscence is a key practice at heritage-based sites (Urry 1996). Importantly, it is a practice that is structured around performance; both that of individual consumers and that of those employed to perform and stimulate memories such as the actors at the Pier. This reminiscing can stimulate the reawakening of dreams and desires, and effect a connection between past and present. Thus, the consumption experience is an active rather than a passive process. However, whilst Urry suggests that it is characteristic of the heritage industry that consumption takes the form of 'a concentrated viewing', my own research indicated that the ability to reminisce is engendered by the embodiment of consumption. It is the physicality of the experience, the capacity of the sites to engage and stimulate a whole range of physical and sensory experiences, and the way the sites engage visitors on an emotional level that is important. Indeed, it is this emotional engagement that promotes the process of remembering at the two sites.It is the reality of the emotions felt by the visitors, the emotional realism, that contributes to their ability to 'perform' at the sites.

This can be highlighted by examining the remarks of visitors who had felt emotionally engaged by the Pier and by contrasting them with some comments made by a group of visitors who had not achieved the same level of emotional closeness. This pattern of divergence can also be detected at the Museum, although it was less marked and less extreme at this site. The cause of this difference was that the Pier made a more direct and explicit appeal to visitors' emotions. More particularly, the Pier more obviously invoked in my subjects a sense of nostalgia as part of the consumption process. Moreover, the Wigan site relied, to a great extent, on the ability of the actors' performances to secure this emotional and imaginary engagement. It is significant that the standard of these performances varied, as did the degree to which such performances engaged the audience. Thus, while visitors to the Museum operated with these imaginary and emotional mappings and engaged in the practice of reminiscence, they were less likely to display such extravagant narratives of emotional engagement or disengagement.

The following comments and the choice of the live performances as a favourite part of their visit by a majority of the visitors highlight the importance of the actors to the emotional engagement of visitors at the Pier. They also indicate the problems that occur if actors' performances do not engage visitors:

'It's very good, you get to enter into that spirit of going back, I mean for me when I looked at one or two things in there, and when we were being told off in the classroom, it took me back to my childhood because it was like that when I was growing up so....' (P22, Male 45, Dermographic Artist), 'I think it's very good actually, l've thoroughly enjoyed it, its much better than just looking round at things and reading bits of plaques about this, that and the other, you know what 
I mean, it brought it to life it really did'(P20, Female 46, Housewife), 'they went in (other people in party, Mum and Niece) but because the little boy was frightened, he went in afterwards, so the acting was very real and it frightened him' (P2, Female 38, Secondary School Teacher) and 'Yes they were very good, yes very natural, very good, good Lancashire accents yes' (P23, Female 69, Retired Farmer)

The following comments indicate that a lack of emotional involvement can diminish an individual's capacity to reminisce. Importantly, this lack of involvement was frequently expressed in terms of disappointment in the live performances at the Pier. A minority of visitors had either not enjoyed the acting performances as much, or were disappointed with both the quality and the quantity of them. One of the visitors, expressing disappointment, focused on the failure of the Pier to live up to expectations:

'Well there was the one chap in the schoolroom, and that was a bit of a disappointment because we'd not been in the schoolroom before and I think we expected a little bit more than we got' (P26, Female 45 Legal Secretary).

Dissatisfaction with the performances also focused on the failure of the actors to live up to past performances

'Yes, but the time I came before there was a woman teacher there and that was far more realistic she terrified everyone, and everybody in there was absolutely silent, but today there was a lot of answering back' (P25, Female 43, Primary School Teacher).

These comments confirm the views of the actors on the diversity of the audience; the actors suggested that they achieved different levels of performance, and varying degrees of engagement with audiences. The degree of emotional engagement and the consequent capacity to reminisce can depend upon the level of performance achieved by the actors. However, the ability of the actors to secure such a performance was itself contingent upon the type of audience.

Significantly, the Schoolroom is the most popular aspect of the site for many visitors. Yet, for the actors it is not the most enjoyable part of their work. This is partly because it is the role that they have to play most often. However, their lack of enjoyment also stems from a reduction in control

'it's the thing that can, the thing that is most dangerous to a certain extent, where you don't know what on earth is going to happen' (Actor 1).

This highlights the complicated and unpredictable relationship between the actors and the visitors, that is further reinforced by the following comments

'It is difficult...you just don't know who you're going to get in the Schoolroom, basically you get some people who take it so seriously' (Actor 2), and 'It's possibly the most tiring part of the day, er, is doing a twenty minute Schoolroom to an audience that are there and then not there, there and then not there. It is a really fine balance, you have between sort of losing it and you have to use all of your skills really in that respect' (Actor 3 ).

Indeed, the actors consider working at the Pier to be 'good experience' because of all the distractions they have to deal with and because 'you have to think on your feet so much' (Actor $3)$.

Different types of audience affect the performances of the actors. Hence, the idea that visitors simplistically accept a nostalgic re-enactment of the past does not capture the reality of the work of the actors at the Pier; neither does it characterize the experience of the audience. This is important as it indicates that visitors do not simply soak up the messages offered to them as is suggested in some influential accounts of heritage (Hewison 1987, 1995, Ascherson 1995). Visitors are far more active and resistant than these accounts have suggested. The relationship with the audience shifts as the actor attempts to maintain the 
authenticity of the performance. Hence, although there are theatrical devices and thus artifice employed to attempt to preserve the illusion of reality, this is a complex process, and as such it is difficult to see how there can be any simple transference of meaning between the actor and the audience. Thus, there was a diversity to the performances and to the audiences that suggests that there was variety and inconsistency to the acting performances at the Pier. There was a complex relationship between the audience and the actors that has consequences for the ability of the Pier to provide visitors with a 'feeling of reliving the past'. The Pier is a place of nostalgia, which uses actors and performers to recreate the past by using 'techniques of embellishment and artifice' (Rojek 1995:120). However, while the performances at the Pier are contrived, Rojek's view is rather simplistic, as it does not recognize the complexity of the relationship between the visitors and the performers. $\mathrm{He}$ assumes that there is an uncomplicated transference of meaning between the heritage that is on offer and visitors' understandings of it. Such accounts neglect the interpretative agency of the visitors. The complex relationship between the audience and the actors challenges the notion of the museum as a place where passive visitors inevitably consume a dominant ideology.

It can also be argued that the performativity of the visitors is assisted by the discursive construction of the sites themselves. Both sites were complex, contested and diverse locations structured by different and frequently competing discourses such as education, entertainment, conservation, commercialization, and marketization. These discourses exist in a tense relationship, at times they are complementary, and at others contradictory. It is the stresses within the production process, both between and within the discourses (Foucault 1980, Purvis and Hunt 1993) that affect the ways in which the two sites present themselves to the public, and how the visitor experiences and consumes them. The sites were not univocal but were multi vocal, and this multiplicity of voices and contestation was reflected in the diverse and complex narratives that visitors used to talk about, and to give meaning to their visits. This complex discursive construction mitigates against any simple transference of meaning from the text of the site to the visitor. As our discussion above has illustrated visitors are able to 'read' the sites in diverse ways. However, it is also important to understand that this diversity can be constraining as well as enabling. These sites are not completely unstructured; rather there are a range of discourses that organize them. Thus, their contestation and diversity does give visitors a degree of flexibility and freedom in their consumption, and does enable deconstruction and reconstruction of the meanings of the sites. However, there are still forms of constraint. These are not unstructured spaces; visitors are offered a particular range of experiences and they are directed to consume the sites in particular ways. There are to a large extent preferred readings, or preferred ways in which to consume and experience the sites, which affect the processes of consumption found there.

However, importantly, this does not mean that this is a passive or non-critical form of consumption. Thus, as the rejective emotional mappings identified earlier indicate, visitors were active and critical in their consumption of the sites. This activity on the part of the audience can also be discerned in the actors' comments about their experiences of the different types of audiences for which they performed and in the ways in which audiences disrupted or challenged the performance. This suggests that the barriers between audience and performers at such sites are fluid and permeable.

\section{Conclusion}

The ability of visitors to perform at such sites is connected to wider matters of social change in the nature of audiences that I have identified above as the paradigm of spectacle and performance. I have argued that my visitors were not passive consumers but skilful and reflexive performers. As people who inhabit a new kind of social space, a mediascape, they are subject to a constant flow of images whilst they also form a new kind of audience that is performatively attuned to the spectacle of the perfomance of others. In such a world visitors are increasingly faced with making choices in their lives, about who they are, or who they want to be. Their biographies become 'do-it-yourself biographies' (Gronow and Warde 2001). As Therborn (2000) has suggested one of the key tenets of 'reflexive modernization' (Beck 
1994:24) is that the modern world is risky, uncertain, contingent, and ambiguous. It is characterized by an increasing 'reflexivity of the self,' or a process of individualization (Bauman 1996, Beck 2000).

Nevertheless, it is important to realize that in emotionally and imaginatively mapping the sites, visitors did not randomly use the whole array of media resources and materials to which they had access; rather they selectively constructed worlds based around their own experiences. Thus, it is important to understand the way in which visitors were able to locate and relate this consumption to memories, biographies and reminiscences. This reflects the tension in contemporary western society between reflexivity of behaviour and the degree to which such behaviour is socially embedded, located in social relations and routines. Indeed, as Campbell (1996) suggests it may well be that many accounts of individualization exaggerate the free and reflexive nature of our behaviour. Importantly, analysis of visitors' consumption of the Museum and the Pier indicates that the process is concerned with performativity, immersion in a mediascape, and the enabling of reflexivity - but significantly it is also firmly located in social relations, and related to memories, cultural and individual biographies. Indeed, visitors' life histories were an important resource in the consumption process. It can be suggested that these aspects of social life are important in the consumption process because they offer security and safety. In particular, visitors used experiences in their everyday lives of work, family and social relationships to enable and enhance the process of emotional and imaginary mapping.

Beck (2000:99) has called for a move away from history as a 'national culture of memory'. Rather, he suggests it is to be conceived as fragmented plural, and cosmopolitan and therefore as optional and as contingent, complex and contradictory as individual memory. These 'landscapes of memory' (Beck 2000:99) are to be understood transnationally. In other words there is the need to break the spell of national memory. Certainly, analysis of visitors' consumption of the Pier and Museum has highlighted the contingent, contradictory and complex qualities of personal memory in the consumption process. However, they are landscapes of memory that are still very firmly located in the routine and everyday lived and experienced worlds of the visitors. It can be suggested that the performativity at the Museum and the Pier embodies a tension between 'spectacular' postmodern forms of consumption and a more embedded form of consumption that is related to social relations, life-histories, and the lived experience of the visitors.

\section{Notes}

${ }^{1}$ On the 31 March 2000 the Museums and Galleries Commission was replaced by Re:source, The Council for Museums, Libraries and Archives.

2 These case studies have entailed obtaining primary data through detailed interviews with, and observation of, visitors to the sites. Significantly, in an attempt to capture the character of this form of consumption, and to move away from individualizing accounts, the majority were not individual interviews. Rather they entailed talking to all members of the visiting party; see figures 1 and 2, appendix 1, for full details of interviewees and composition of visiting groups. Further sources of information came from interviews with staff, including actors and other members of Wigan Pier Theatre Company, management and associates of the sites. Other data have been generated through examination of archival records at each site, including official records, pamphlets and guidebooks, and visitor surveys. Thus, the intention of the research was to combine and integrate a qualitative research design with an analysis of administrative records and documents.

${ }^{3}$ It is important to note the use of the term audience here, in much recent writing on museums and heritage sites. There is a deal of slippage between the idea of an audience and visitors. The two words are often used to describe the same phenomenon; people visiting a specific site. Thus, there is talk of 'audience profiles' rather than 'visitor profiles' of particular sites (see Mathers 1996, Hooper-Greenhill 1997). However, the term audience can also imply 
something wider than actual visitors to a site. It may suggest potential visitors. Thus, the audience for a museum can embrace visitors and non-visitors. The use of the term audience can be connected to the increase in research that focuses on the visitors and non-visitors to sites, and the changes that have occurred in museums. Moreover, a visit to a museum now has much in common with other forms of cultural activity such as the theatre, cinema, or theme park. However, it is important to recognize that the term audience suggests a degree of homogeneity that can be challenged. Rather it is better to acknowledge that visitors are part of a variety of diverse audiences at the sites. Hence it is suggested that at various points in their visit people are constructed into a variety of audiences, such as an audience for a live performance, or an audio-visual presentation. In this article when I am talking about visitors to specific sites I will employ the word visitors to emphasize that these were people at the sites on a specific day. However, it is important to note that these visitors were and are very much audiences in a variety of ways.

${ }^{4}$ The concept of mapping, and in particular of mental mapping, is derived from work in geographical studies, where it has been suggested that individuals use mental maps to facilitate an understanding of the world in which they live (Downs 1977). This cognitive mapping is a process that people engage in rather than an object they have. Kevin Lynch (1960) uses the concept of mental mapping in his spatial analysis of the city. The experience of the city is presented as a dialectic between the 'here and now of immediate perception and the imaginative or imaginary sense of the city as an absent totality' (Jameson 1988:353). Jameson (1988:353) takes up this notion, to suggest that an 'aesthetic of cognitive mapping' is integral to any socialist political project, and that Lynch's mental map of city space can be extrapolated to the mental map of social and global totality people carry around in their heads. The work of Jameson is important and suggestive because previously most work on mental or cognitive mapping had tended to concentrate on visual representations of different environments, whereas, Jameson attempts to locate this mapping in a more sociological context.

${ }^{5}$ See figures 1 and 2, appendix 1, for details of interviewees and composition of visiting parties 


\section{Appendix 1}

Figure 1. Composition of visitor interview groups: Museum visitors

\begin{tabular}{|c|c|c|c|}
\hline Group & Gender & Age & Occupation \\
\hline M1 & $\begin{array}{l}\text { Male } \\
\text { Female } \\
\text { Male }\end{array}$ & $\begin{array}{l}52 \\
48 \\
14\end{array}$ & $\begin{array}{l}\text { Primary School Head Teacher } \\
\text { Primary School Teacher }\end{array}$ \\
\hline M2 & Male & 31 & Electrical Technician \\
\hline M3 & $\begin{array}{l}\text { Female } \\
\text { Female } \\
\text { Female }\end{array}$ & $\begin{array}{r}36 \\
11 \\
6\end{array}$ & Undergraduate Student - B.Ed \\
\hline M4 & $\begin{array}{l}\text { Female } \\
\text { Male } \\
\text { Female }\end{array}$ & $\begin{array}{r}35 \\
33 \\
6\end{array}$ & Office \& Delivery Ass- Car Parts Motor Mechanic \\
\hline M5 & $\begin{array}{l}\text { Female } \\
\text { Male } \\
\text { Male }\end{array}$ & $\begin{array}{l}44 \\
15 \\
11\end{array}$ & University Researcher - Archaeology \\
\hline M6 & $\begin{array}{l}\text { Male } \\
\text { Female }\end{array}$ & $\begin{array}{l}31 \\
33 \\
\end{array}$ & $\begin{array}{l}\text { Coach Firm Proprietor } \\
\text { Coach Firm Proprietor }\end{array}$ \\
\hline M7 & $\begin{array}{l}\text { Female } \\
\text { Male } \\
\text { Female } \\
\text { Male } \\
\text { Female }\end{array}$ & $\begin{array}{r}43 \\
43 \\
12 \\
9 \\
6 \\
\end{array}$ & $\begin{array}{l}\text { Housewife } \\
\text { Company Director Engineering Company }\end{array}$ \\
\hline M8 & $\begin{array}{l}\text { Male } \\
\text { Female } \\
\text { Female }\end{array}$ & $\begin{array}{r}37 \\
10 \\
5\end{array}$ & Company Director Wholesale Packaging \\
\hline M9 & $\begin{array}{l}\text { Male } \\
\text { Female } \\
\text { Female } \\
\text { Female } \\
\text { Male }\end{array}$ & $\begin{array}{r}42 \\
36 \\
10 \\
10 \\
7\end{array}$ & $\begin{array}{l}\text { Primary School Teacher } \\
\text { Adult Education Worker }\end{array}$ \\
\hline M10 & $\begin{array}{l}\text { Male } \\
\text { Female } \\
\text { Female } \\
\text { Female } \\
\text { Male }\end{array}$ & $\begin{array}{l}46 \\
40 \\
17 \\
13 \\
11\end{array}$ & $\begin{array}{l}\text { Builder - Self Employed } \\
\text { Domestic }\end{array}$ \\
\hline M11 & $\begin{array}{l}\text { Male } \\
\text { Female }\end{array}$ & $\begin{array}{l}25 \\
23\end{array}$ & $\begin{array}{l}\text { Contracts Manager - Construction } \\
\text { Primary School Teacher }\end{array}$ \\
\hline M12 & $\begin{array}{l}\text { Male } \\
\text { Female }\end{array}$ & $\begin{array}{l}33 \\
31 \\
\end{array}$ & $\begin{array}{l}\text { Electrician - Self Employed } \\
\text { Building Society Cashier }\end{array}$ \\
\hline M13 & $\begin{array}{l}\text { Male } \\
\text { Female }\end{array}$ & $\begin{array}{l}56 \\
56\end{array}$ & $\begin{array}{l}\text { Chartered Structural Engineer } \\
\text { Receptionist }\end{array}$ \\
\hline M14 & $\begin{array}{l}\text { Female } \\
\text { Male }\end{array}$ & $\begin{array}{r}50 \\
9\end{array}$ & Housewife \\
\hline M15 & $\begin{array}{l}\text { Female } \\
\text { Male } \\
\text { Female } \\
\text { Female } \\
\text { Male }\end{array}$ & $\begin{array}{r}34 \\
33 \\
12 \\
9 \\
2\end{array}$ & $\begin{array}{l}\text { Bakery Assistant } \\
\text { Taxi Driver }\end{array}$ \\
\hline M16 & $\begin{array}{l}\text { Male } \\
\text { Female }\end{array}$ & $\begin{array}{l}58 \\
29\end{array}$ & $\begin{array}{l}\text { Electrical Engineer - Power Station } \\
\text { Secondary School Teacher - Music }\end{array}$ \\
\hline M17 & $\begin{array}{l}\text { Male } \\
\text { Female } \\
\text { Female }\end{array}$ & $\begin{array}{r}47 \\
41 \\
9\end{array}$ & $\begin{array}{l}\text { Industrial Scientist } \\
\text { Childminder }\end{array}$ \\
\hline
\end{tabular}




\begin{tabular}{|c|c|c|c|}
\hline M18 & $\begin{array}{l}\text { Female } \\
\text { Female } \\
\text { Male } \\
\text { Male }\end{array}$ & $\begin{array}{r}67 \\
36 \\
35 \\
4 \\
\end{array}$ & $\begin{array}{l}\text { Retired } \\
\text { Biometrics Team Leader - Statistician } \\
\text { House Husband - pr Software Engnr }\end{array}$ \\
\hline M19 & Female & 56 & Midwifery Manager - Visit with Saga \\
\hline M20 & $\begin{array}{l}\text { Female } \\
\text { Male }\end{array}$ & $\begin{array}{l}20 \\
20\end{array}$ & $\begin{array}{l}\text { Pharmacology Undergraduate } \\
\text { Psychology Undergraduate }\end{array}$ \\
\hline M21 & $\begin{array}{l}\text { Male } \\
\text { Male }\end{array}$ & $\begin{array}{l}33 \\
32\end{array}$ & $\begin{array}{l}\text { Sales Manager - USA } \\
\text { Sales Manager - USA }\end{array}$ \\
\hline M22 & $\begin{array}{l}\text { Female } \\
\text { Male } \\
\text { Female }\end{array}$ & $\begin{array}{l}50 \\
49 \\
19\end{array}$ & $\begin{array}{l}\text { Housewife } \\
\text { Sales Assistant } \\
\text { Undergraduate B.Ed }\end{array}$ \\
\hline M23 & $\begin{array}{l}\text { Male } \\
\text { Female } \\
\text { Male } \\
\text { Female }\end{array}$ & $\begin{array}{r}39 \\
36 \\
7 \\
7 \\
\end{array}$ & $\begin{array}{l}\text { Quantity Surveyor } \\
\text { Purchase \& Ledger \& Accounts Clerk }\end{array}$ \\
\hline M24 & $\begin{array}{l}\text { Male } \\
\text { Female }\end{array}$ & $\begin{array}{l}23 \\
21\end{array}$ & $\begin{array}{l}\text { Motor Mechanic } \\
\text { Retail Assistant }\end{array}$ \\
\hline M25 & $\begin{array}{l}\text { Male } \\
\text { Female }\end{array}$ & $\begin{array}{l}53 \\
53\end{array}$ & $\begin{array}{l}\text { Aircraft Engineer } \\
\text { Medical Secretary }\end{array}$ \\
\hline M26 & $\begin{array}{l}\text { Male } \\
\text { Female }\end{array}$ & $\begin{array}{l}51 \\
51\end{array}$ & $\begin{array}{l}\text { Primary Head Teacher } \\
\text { Medical Secretary }\end{array}$ \\
\hline M27 & $\begin{array}{l}\text { Male } \\
\text { Female } \\
\text { Male }\end{array}$ & $\begin{array}{r}33 \\
32 \\
4 \\
\end{array}$ & $\begin{array}{l}\text { Machine Operator } \\
\text { Nursery Assistant }\end{array}$ \\
\hline M28 & $\begin{array}{l}\text { Male } \\
\text { Female }\end{array}$ & $\begin{array}{l}48 \\
24\end{array}$ & $\begin{array}{l}\text { Architect } \\
\text { Cost Controller }\end{array}$ \\
\hline M29 & $\begin{array}{l}\text { Male } \\
\text { Female }\end{array}$ & $\begin{array}{l}54 \\
51\end{array}$ & $\begin{array}{l}\text { Sales Manager } \\
\text { Cashier - Turf Accountant }\end{array}$ \\
\hline M30 & $\begin{array}{l}\text { Male } \\
\text { Male }\end{array}$ & $\begin{array}{r}50 \\
4 \\
\end{array}$ & Salvage Dealer - Own Company \\
\hline M31 & $\begin{array}{l}\text { Female } \\
\text { Male } \\
\text { Male } \\
\text { Male }\end{array}$ & $\begin{array}{l}49 \\
42 \\
14 \\
13 \\
\end{array}$ & $\begin{array}{l}\text { Retail Assistant } \\
\text { Helicopter Pilot-Commercial }\end{array}$ \\
\hline M32 & $\begin{array}{l}\text { Female } \\
\text { Female } \\
\text { Male }\end{array}$ & $\begin{array}{r}41 \\
14 \\
2 \\
\end{array}$ & Radiographer \\
\hline M33 & $\begin{array}{l}\text { Female } \\
\text { Male } \\
\text { Female }\end{array}$ & $\begin{array}{r}35 \\
27 \\
9\end{array}$ & $\begin{array}{l}\text { Primary School Teacher } \\
\text { Secondary School Teacher }\end{array}$ \\
\hline M34 & $\begin{array}{l}\text { Female } \\
\text { Female } \\
\text { Female } \\
\text { Female } \\
\text { Male } \\
\text { Male } \\
\text { Female }\end{array}$ & $\begin{array}{r}38 \\
38 \\
7 \\
7 \\
5 \\
4 \\
1\end{array}$ & $\begin{array}{l}\text { General Practitioner } \\
\text { PhD Student - Biochemistry }\end{array}$ \\
\hline M35 & $\begin{array}{l}\text { Male } \\
\text { Female }\end{array}$ & $\begin{array}{l}44 \\
10\end{array}$ & University Lecturer - History \\
\hline
\end{tabular}




\section{Figure 2 Composition of visitor interview groups: Pier visitors}

\begin{tabular}{|c|c|c|c|}
\hline Group & Gender & Age & Occupation \\
\hline P1 & $\begin{array}{l}\text { Male } \\
\text { Female } \\
\text { Female14 } \\
\text { Female5 } \\
\text { Male1 }\end{array}$ & $\begin{array}{l}33 \\
31\end{array}$ & $\begin{array}{l}\text { Social Worker } \\
\text { Secretary }\end{array}$ \\
\hline P2 & $\begin{array}{l}\text { Female } \\
\text { Female } \\
\text { Female } \\
\text { Male5 }\end{array}$ & $\begin{array}{l}74 \\
38 \\
17\end{array}$ & $\begin{array}{l}\text { Retired } \\
\text { Secondary School Teacher (English) } \\
\text { A' Level Student }\end{array}$ \\
\hline P3 & $\begin{array}{l}\text { Male } \\
\text { Female } \\
\text { Female } \\
\text { Female }\end{array}$ & $\begin{array}{r}35 \\
31 \\
7 \\
5 \\
\end{array}$ & $\begin{array}{l}\text { Structural Engineer } \\
\text { Secretary }\end{array}$ \\
\hline P4 & $\begin{array}{l}\text { Male } \\
\text { Female } \\
\text { Female }\end{array}$ & $\begin{array}{r}35 \\
34 \\
8\end{array}$ & $\begin{array}{l}\text { Police Officer/Sergeant } \\
\text { Housewife prev Insurance Clerk }\end{array}$ \\
\hline P5 & $\begin{array}{l}\text { Male } \\
\text { Female } \\
\text { Male }\end{array}$ & $\begin{array}{r}50 \\
49 \\
1\end{array}$ & $\begin{array}{l}\text { Building Contractor/Shop Proprietor } \\
\text { Building Contractor/Shop Proprietor }\end{array}$ \\
\hline P6 & $\begin{array}{l}\text { Female } \\
\text { Male } \\
\text { Female } \\
\text { Male } \\
\end{array}$ & $\begin{array}{r}37 \\
36 \\
8 \\
6 \\
\end{array}$ & $\begin{array}{l}\text { School Nurse - RGN } \\
\text { Commercial Helicopter Pilot }\end{array}$ \\
\hline P7 & Female & 83 & $\begin{array}{l}\text { Retired/Prev Coal Pit Worker (visiting with coach party from } \\
\text { Blackpool) }\end{array}$ \\
\hline P8 & $\begin{array}{l}\text { Male } \\
\text { Female } \\
\text { Male } \\
\text { Female } \\
\text { Male } \\
\text { Female } \\
\text { Female }\end{array}$ & $\begin{array}{l}46 \\
42 \\
21 \\
16 \\
13 \\
12 \\
11\end{array}$ & $\begin{array}{l}\text { Chemistry Lecturer } \\
\text { Housewife } \\
\text { Student }\end{array}$ \\
\hline P9 & $\begin{array}{l}\text { Female } \\
\text { Female } \\
\text { Female }\end{array}$ & $\begin{array}{l}55 \\
30 \\
29\end{array}$ & $\begin{array}{l}\text { Housewife } \\
\text { Hospital Nurse - RGN } \\
\text { P.E. Lecturer - Further Education College }\end{array}$ \\
\hline P10 & $\begin{array}{l}\text { Male } \\
\text { Female }\end{array}$ & $\begin{array}{l}27 \\
21\end{array}$ & $\begin{array}{l}\text { Chef } \\
\text { Auxiliary Nurse }\end{array}$ \\
\hline P11 & $\begin{array}{l}\text { Female } \\
\text { Female } \\
\text { Female }\end{array}$ & $\begin{array}{l}59 \\
58 \\
58\end{array}$ & $\begin{array}{l}\text { Retired Publican } \\
\text { Retired Accountant } \\
\text { Retired Insurance Clerk }\end{array}$ \\
\hline P12 & $\begin{array}{l}\text { Male } \\
\text { Female }\end{array}$ & $\begin{array}{l}35 \\
29 \\
\end{array}$ & $\begin{array}{l}\text { Bank Official - Assistant Manager } \\
\text { Insurance Administrator }\end{array}$ \\
\hline P13 & $\begin{array}{l}\text { Male } \\
\text { Female }\end{array}$ & $\begin{array}{l}26 \\
21\end{array}$ & $\begin{array}{l}\text { Mail Order Clerk } \\
\text { Mail Order Clerk }\end{array}$ \\
\hline P14 & $\begin{array}{l}\text { Male } \\
\text { Female } \\
\text { Female } \\
\text { Male }\end{array}$ & $\begin{array}{r}38 \\
35 \\
6 \\
3\end{array}$ & $\begin{array}{l}\text { Hairdresser- Proprietor } \\
\text { Hairdresser- Proprietor }\end{array}$ \\
\hline P15 & $\begin{array}{l}\text { Female } \\
\text { Male } \\
\text { Female }\end{array}$ & $\begin{array}{l}42 \\
41 \\
11\end{array}$ & $\begin{array}{l}\text { Hospital Nurse - RGN } \\
\text { Ship's Captain }\end{array}$ \\
\hline P16 & $\begin{array}{l}\text { Female } \\
\text { Male } \\
\text { Male } \\
\text { Male } \\
\text { Male }\end{array}$ & $\begin{array}{r}42 \\
37 \\
12 \\
7\end{array}$ & $\begin{array}{l}\text { Classroom Assistant } \\
\text { Printer }\end{array}$ \\
\hline
\end{tabular}




\begin{tabular}{|c|c|c|c|}
\hline P17 & $\begin{array}{l}\text { Male } \\
\text { Female }\end{array}$ & $\begin{array}{l}42 \\
39 \\
\end{array}$ & $\begin{array}{l}\text { International Sales Representative } \\
\text { Primary School Teacher }\end{array}$ \\
\hline P18 & $\begin{array}{l}\text { Female } \\
\text { Female } \\
\text { Male }\end{array}$ & $\begin{array}{l}44 \\
42 \\
19\end{array}$ & $\begin{array}{l}\text { Beauty Therapist } \\
\text { Football Pools Clerk } \\
\text { Horticulture Student }\end{array}$ \\
\hline P19 & $\begin{array}{l}\text { Male } \\
\text { Female } \\
\text { Male } \\
\text { Female } \\
\end{array}$ & $\begin{array}{l}49 \\
43 \\
16 \\
11\end{array}$ & $\begin{array}{l}\text { Driving Instructor - Self Employed } \\
\text { Housewife }\end{array}$ \\
\hline P20 & $\begin{array}{l}\text { Female } \\
\text { Male } \\
\text { Male }\end{array}$ & $\begin{array}{l}46 \\
45 \\
12 \\
\end{array}$ & $\begin{array}{l}\text { Housewife } \\
\text { Taxi Driver }\end{array}$ \\
\hline P21 & $\begin{array}{l}\text { Female } \\
\text { Female } \\
\text { Female }\end{array}$ & $\begin{array}{l}81 \\
80 \\
79\end{array}$ & $\begin{array}{l}\text { Retired - Retail Assistant } \\
\text { Retired - Home Help } \\
\text { Retired - Insurance Collector }\end{array}$ \\
\hline P22 & $\begin{array}{l}\text { Male } \\
\text { Female }\end{array}$ & $\begin{array}{l}45 \\
44\end{array}$ & $\begin{array}{l}\text { Demographic Artist- Self Employed } \\
\text { Auxiliary Nurse }\end{array}$ \\
\hline P23 & $\begin{array}{l}\text { Male } \\
\text { Female }\end{array}$ & $\begin{array}{l}74 \\
69\end{array}$ & $\begin{array}{l}\text { Retired - Farmer owned farm } \\
\text { Retired - Farmer owned farm }\end{array}$ \\
\hline P24 & $\begin{array}{l}\text { Male } \\
\text { Female } \\
\text { Male } \\
\text { Female }\end{array}$ & $\begin{array}{l}75 \\
70 \\
65 \\
59\end{array}$ & $\begin{array}{l}\text { Retired - Steel Worker } \\
\text { Retired - Care Assistant } \\
\text { Retired - Joiner } \\
\text { Retired - Senior Care Assistant }\end{array}$ \\
\hline P25 & $\begin{array}{l}\text { Male } \\
\text { Female } \\
\text { Female }\end{array}$ & $\begin{array}{l}48 \\
48 \\
43 \\
\end{array}$ & $\begin{array}{l}\text { Technical Manager - Bakery } \\
\text { Primary School Teacher } \\
\text { Primary School Teacher }\end{array}$ \\
\hline P26 & $\begin{array}{l}\text { Female } \\
\text { Female } \\
\text { Female }\end{array}$ & $\begin{array}{l}55 \\
45 \\
38\end{array}$ & $\begin{array}{l}\text { Retail Manager } \\
\text { Legal Secretary } \\
\text { Finance Manager }\end{array}$ \\
\hline P27 & $\begin{array}{l}\text { Female } \\
\text { Female } \\
\text { Female } \\
\text { Male } \\
\text { Female }\end{array}$ & $\begin{array}{l}74 \\
47 \\
34 \\
33 \\
24\end{array}$ & $\begin{array}{l}\text { Retired } \\
\text { Retired } \\
\text { Accounts Clerk } \\
\text { Engineering Surveyor } \\
\text { Clerical Officer }\end{array}$ \\
\hline P28 & $\begin{array}{l}\text { Male } \\
\text { Female }\end{array}$ & $\begin{array}{l}74 \\
61\end{array}$ & $\begin{array}{l}\text { Retired - Coal Board Fitter } \\
\text { Retired Civil Servant }\end{array}$ \\
\hline P29 & $\begin{array}{l}\text { Male } \\
\text { Female }\end{array}$ & $\begin{array}{l}55 \\
54\end{array}$ & $\begin{array}{l}\text { Engineer } \\
\text { Housewife }\end{array}$ \\
\hline P30 & $\begin{array}{l}\text { Female } \\
\text { Male }\end{array}$ & $\begin{array}{l}53 \\
47 \\
\end{array}$ & $\begin{array}{l}\text { Secretary } \\
\text { Mechanical Technician }\end{array}$ \\
\hline P31 & $\begin{array}{l}\text { Female } \\
\text { Female } \\
\text { Female }\end{array}$ & $\begin{array}{l}50 \\
29 \\
27\end{array}$ & $\begin{array}{l}\text { Retail Assistant } \\
\text { Retail Assistant } \\
\text { Unemployed } \\
\end{array}$ \\
\hline P32 & $\begin{array}{l}\text { Male } \\
\text { Female }\end{array}$ & $\begin{array}{l}51 \\
48\end{array}$ & $\begin{array}{l}\text { Draughtsman } \\
\text { Swimming Instructor }\end{array}$ \\
\hline P33 & $\begin{array}{l}\text { Female } \\
\text { Male } \\
\text { Male1 }\end{array}$ & $\begin{array}{l}25 \\
24\end{array}$ & $\begin{array}{l}\text { Secretary } \\
\text { Plumber }\end{array}$ \\
\hline P34 & $\begin{array}{l}\text { Female } \\
\text { Female }\end{array}$ & $\begin{array}{l}71 \\
43\end{array}$ & $\begin{array}{l}\text { Retired-Machinist } \\
\text { Office Administrator }\end{array}$ \\
\hline P35 & $\begin{array}{l}\text { Male } \\
\text { Female } \\
\text { Female }\end{array}$ & $\begin{array}{l}48 \\
39 \\
14\end{array}$ & $\begin{array}{l}\text { Private Detective - Self Employed } \\
\text { Hospital Clerk }\end{array}$ \\
\hline
\end{tabular}




\section{References}

Abercrombie, N. and Longhurst, B. (1998) Audiences, London: Sage.

Ang, I. (1985) Watching Dallas: Soap Opera and the Melodramatic Imagination, London: Methuen.

Ang, I. (1996) Living Room Wars, London: Routledge.

Appadurai, A. (1993) 'Disjuncture and Difference in the Global Cultural Economy', in B. Robins (ed), The Phantom Public Sphere, Minneapolis and London: University of Minnesota Press.

Ascherson, N. (1995), 'Down Memory Lane', Interview with B. Butler in Museums Journal, (April) 15-17.

Bagnall. G. (1996) 'Consuming the Past' in S. Edgell, K. Hetherington and A. Warde, (eds) Consumption Matters, Oxford: Blackwell.

Bagnall, G., Longhurst, B. and Savage, M. (1997) 'Social Class Lifestyles and Urban Networks', unpublished paper presented to the Annual Conference of the British Sociological Association, York, 1997.

Batty, C. (1996) 'Warning: Museums Can Damage Your Health' MAG: London Museums and Galleries Magazine, Issue 3 London.

Bauman, G. (1996), Contesting Culture-Discourses of Identity in Multiethinic London, Cambridge: Cambridge University Press.

Beck, U. (1994) 'The Re-invention of Politics: Towards a Theory of Reflexive Modernization' in U. Beck, A. Giddens and S. Lash, Reflexive Modernization, Cambridge: Polity Press.

Beck, U. (2000) 'The Cosmopolitan Perspective: Sociology of the Second Age of Modernity' The British Journal of Sociology 51(1), 79-106.

Bourdieu, P. (1984) Distinction: A Social Critique of the Judgement of Taste, London: Routledge \& Kegan Paul.

Campbell, C. (1987) The Romantic Ethic and the Spirit of Modern Consumerism, Oxford: Basil Blackwell.

Campbell, C. (1996) 'Detraditionalization, Character and the Limits of Agency' in P. Heelas, S. Lash and P. Morris, (eds) Detraditionalization: Critical Reflections on Authority and Identity, Cambridge: Blackwell.

De Certeau, M. (1984) The Practice of Everyday life, Berkeley: University of California Press.

Downs, R. M. (1977) Maps in Minds: Reflections on Cognitive Mapping, London: Harper and Row.

Duncombe, J.and Marsden, D. (1993) 'Love and Intimacy: the Gender Division of Emotion and Emotion Work', Sociology, 27 (1), 221-241.

Foucault, M. (1980) Power/Knowledge: Selected Interviews and other Writings, 1972-1977, $C$. Gordon (trans and ed) Brighton: Harvester Press.

Game, A. (1991) Undoing the Social, Milton Keynes: Open University Press.

Gronow., J. and Warde., A. (2001) 'Epilogue: Conventional Consumption' in J. Gronow and A. Warde, Ordinary Consumption, Aldershot: Ashgate 
Hewison, R. (1987) The Heritage Industry, London: Methuen.

Hewison, R. (1995) 'Down Memory Lane', (interview with B. Butler) in Museums Journal, (April) 15-17.

Hooper-Greenhill, E. (1997) 'Towards Plural Perspectives' in E. Hooper-Greenhill (ed), Cultural Diversity, Developing Museum Audiences in Britain' London: Leicester University Press.

Hochschild, A. (1983) The Managed Heart: the Commercialization of Human Feeling, Berkeley: University of California Press.

Jameson, F. (1988) Cognitive Mapping, in C. Nelson and L. Grossberg (eds), Marxism and the Interpretation of Culture, London: Macmillan.

Lynch, K. (1960), The Image of the City, Cambridge: MIT Press.

Mathers, K. (1996), Museums, Galleries and New Audiences, London: Art and Society

Morley, D. (1980), The 'Nationwide’ Audience, London: British Film Institute

Museum of Science and Industry in Manchester, (nd), 'The Museum of Science \& Industry in Manchester', Manchester: The Museum of Science \& Industry.

Purvis T. and Hunt, A. (1993), 'Discourse, Ideology, Discourse, Ideology,

Discourse, ideology,...' The British Journal of Sociology, 44 (3), 473-499.

Reigel, H. (1996) 'Into the Heart of Irony: Ethnographic Exhibitions and the Politics of Difference', in S. Macdonald and G. Fyfe (eds), Theorizing Museums, Oxford: Blackwell.

Rojek, C. (1995) Decentring Leisure, London: Sage.

Sande, B. (1984) 'Presenting the truth about the past' CRM Bulletin, 7 (4) 2-4.

Savage, M. (1983) 'Walter Benjamin and urban meaning', Working Papers No 3. Keele University, Keele: Department of Sociology and Social Anthropology.

Therborn, G. (2000), 'At the Birth of Second Century Sociology: Times of Reflexivity, Spaces of Identity and Nodes of Knowledge,' The British Journal of Sociology 51 (1), 37-58.

Urry, J. (1996) 'How Societies Remember the Past,' in S. Macdonald and G. Fyfe (eds), Theorizing Museums, Oxford: Blackwell.

Warde, A. Martens, L. and Olsen, W. (1999) 'Consumption and the Problem of Variety: Cultural Omnivorousness, Social Distinction and Eating Out', Sociology, 33 (1), 105-127.

Wouters, C. (1989) 'The Sociology of Emotions and Flight Attendants: Hochschild's managed heart', Theory Culture and Society, 6 (1), 95-123.

* Gaynor Bagnall is Lecturer in the sociology of consumption at Liverpool John Moores University where she researches into consumption practices and representations of the past. Her work embraces identity, performance and performativity at heritage sites and museums. She is also interested in life history and narrative as they relate to reminiscence. Dr Bagnall has published a wide range of papers. These include 'Consuming the Past' in S. Edgell et al. (eds) Consumption Matters Blackwell 1996 and 'Ordinary Consumption and Personal Identity' (with Mike Savage and Brian Longhurst) in Ordinary Consumption edited by J. Gronow and Alan Warde (Routledge 2001) . 